\title{
Evaluation of trawling disturbance on macrobenthic invertebrate communities in the Bay of Biscay, France: Abundance Biomass Comparison (ABC method)
}

\author{
Rémi Vergnon ${ }^{1}$ and Fabian Blanchard ${ }^{2, a}$ \\ 1 University of Sheffield, Department of Animal and Plant Sciences, Western Bank, Sheffield S10 2TN, UK \\ 2 IFREMER, Département halieutique méditerranéen et tropical, Domaine de Suzini, BP 477, 97331 Cayenne, Guyane française
}

Received 31 May 2005; Accepted 30 August 2006

\begin{abstract}
The necessity to move from a traditional fishery management to an ecosystem approach is now acknowledged. Indicators are required to support the development of this approach. For example, community indicators have been proposed to assess the impact of fishing. We tested here the applicability of one such community indicator, the abundance-biomass comparison ( $\mathrm{ABC}$ method), as a measure of the impact of bottom trawling (years of sampling: 2001 and 2003) on the benthic invertebrates - typically starfishes, crabs, squat lobsters, shrimps and large hard-shelled molluscs- of "Grande Vasière", a major French fishing zone, in the Bay of Biscay. The ABC method is generally used as an impact indicator for different types of physical, biological and anthropogenic disturbances on benthic communities. This method is based on the assumption that increasing disturbance shifts communities from dominance by large-bodied species with low turnover rates toward dominance by small-bodied species with high turnover rates. At less disturbed areas the average biomass of individuals is greater than at more heavily disturbed areas. The ABC method measures this effect by comparing the ranked distributions of abundance and biomass within a given community. We applied the $\mathrm{ABC}$ method and compared the size structure and the species diversity at two areas exposed to moderate and high bottom trawl effort. Species diversity was lower in the most exploited area. The highly trawled area was dominated by opportunistic organisms, mainly one species of swimming crab Liocarcinus depurator, one species of squat lobster Munida rugosa and Norway lobsters Nephrops norvegicus, which are large-bodied species. Consequently, the results of the $\mathrm{ABC}$ method were inconsistent with the theoretical expectation for these particular macrofaunal communities and the measured levels of fishing intensity.
\end{abstract}

Key words: Bottom trawl survey / Indicator / Fishing impact/ ABC method / Macrobenthos / Density / Inter-annual variability / Atlantic Ocean

\begin{abstract}
Résumé - Évaluation de la perturbation due au chalutage fond sur une communauté de macro-invertébrés benthiques dans le golfe de Gascogne, France : comparaison abondance-biomasse (méthode ABC). La nécessité de passer d'une gestion monospécifique des pêches à une approche écosystémique est largement reconnue. Pour mettre en place une telle approche, des indicateurs ont été proposés afin d'estimer l'impact de la pêche sur les communautés. Nous avons testé l'efficacité de l'un de ces indicateurs, la comparaison abondance-biomasse (méthode ABC), pour mesurer l'impact du chalutage de fond (année d'échantillonnage : 2001 et 2003) sur les communautés de la macrofaune benthique de la Grande Vasière, golfe de Gascogne (typiquement des crabes, étoiles de mer, des galathées, de gros mollusques à coquille dure). La méthode $\mathrm{ABC}$ est généralement utilisée comme un indicateur d'impact de différents types de perturbations physiques, biologiques et anthropiques sur les communautés benthiques. Cette méthode est basée sur l'hypothèse qu'un régime de perturbation croissant entraîne une modification de la structure des communautés qui deviennent graduellement dominées par des espèces opportunistes de petite taille caractérisées par un renouvellement rapide. Dans une communauté modérément perturbée, la biomasse moyenne des individus est ainsi plus grande que dans une communauté fortement perturbée. La méthode $\mathrm{ABC}$ mesure cet effet en comparant les distributions en biomasse et densité dans chaque communauté. Nous avons appliqué la méthode $\mathrm{ABC}$ et étudié la structure en taille et la diversité spécifique des communautés benthiques en comparant deux zones, l'une soumise à un effort de pêche modéré et l'autre à un important effort de pêche. La diversité spécifique était plus faible sur les sites fortement chalutés. Ces sites étaient dominés par des organismes opportunistes de grande taille, principalement une espèce de crabe nageur Liocarcinus depurator, une espèce de galathée Munida rugosa et des langoustines Nephrops norvegicus. Dans ces conditions, les résultats de la méthode $\mathrm{ABC}$ n'étaient pas cohérents avec la théorie pour ces communautés de macro-invertébrés benthiques et les efforts de pêche mesurés.
\end{abstract}

a Corresponding author: Fabian.Blanchard@ifremer.fr 


\section{Introduction}

The abundance-biomass comparison (ABC method) has been first used to detect and measure the effects of pollution on macrobenthic communities (Warwick 1986). Its applications have been progressively extended to other communities submitted to physical, biological (Warwick et al. 1987) and anthropic disturbances (Lindeboom and de Groot 1998; Kaiser et al. 2000). In theory, this graphic indicator does not need any control data (undisturbed state) to provide measures of community health. It has then appeared very attractive for monitoring and assessing impact at ecosystem scales because control sites undisturbed by human impact are increasingly difficult to find.

The ABC method assumes that the distributions of biomass and abundance in benthic communities show a differential response to disturbance. Results are presented as combined $\mathrm{K}$-dominance plots for species biomass and abundance. For each of the two parameters, the K-dominance curve is built by plotting on the $Y$-axis the relative contribution of each species ranked on the $X$-axis, by decreasing order of importance.

According to the ecological succession theory - the predicted evolution of community structure with disturbance (Connell 1978) - Warwick proposed three different forms of combined K-dominance plots figuring increasing levels of disturbance (Fig. 1). Undisturbed communities tend to be dominated by large-bodied, long-lived species represented by a small number of individuals with low turnover rates. The biomass curve lies then above the abundance curve throughout its entire length - reflecting the larger average size of each individual. In moderately disturbed communities, the frequency and intensity of disturbance impose sufficient mortality to eliminate the large species with lower population growth rates. The remaining community is dominated by smaller-bodied, short-lived species with high population growth rates and the difference between the biomass curve and the abundance curve decreases toward zero. In grossly disturbed communities, the domination of small-bodied species increases and the abundance curve lies above the biomass curve throughout its entire length.

Soft bottom communities support productive fisheries for crustaceans, flatfishes and some demersal roudfishes, such as hake (Merluccius merluccius). Benthic trawling is a major disturbance source of disturbance in soft-sediment communities. The massive increase of fishing effort and trawling has modified the structure of benthic communities (Kaiser et al. 1998, 2000; Jennings 2001) through differential mortalities depending on individual size, life mode, morphology and demography. Overexploitation removes the most sensitive species, which may indirectly modify food web functioning by favouring opportunistic species which are able to feed on the additional trophic resources represented by discards and organisms killed or injured by the gears (Bergmann 2002b). The alteration of the structural and functional integrity of benthic habitats by trawling could then have consequences for fisheries productivity. Furthermore, the ecosystem approach to fisheries management aims to managing exploitable resources while retaining important biodiversity. Thus, it would be relevant to measure the fishing impact on the benthic communities (Hall 1999).
In order to measure fishing impacts on ecosystems, a wide range of quantitative indicators are being developed (Cury and Christensen 2005). One such indicator, the ABC method, appears to have some promise for measuring fishing effects and its implementation had been proposed (Lindeboom and de Groot 1998; Tuck et al. 1998; Kaiser et al. 2000; Blanchard et al. 2004). Although the majority of exploited benthic species belongs to large macrofauna (organisms which size is greater than $1 \mathrm{~cm}$ ), the $\mathrm{ABC}$ method had not been applied yet to this group of organisms. We assessed the impact of moderate and high levels of bottom trawling on benthic macrofaunal communities using both the $\mathrm{ABC}$ method and measures of diversity and size structure. The benthic macrofaunal communities subject to a high and a moderate fishing effort were sampled in May 2001 and November 2003 on the Grande Vasière (Bay of Biscay, France). To estimate whether the ABC method could be used as an ecological measure of fishing impact, structural differences between moderately and highly exploited communities were analysed. We compared species richness, mean individual weights, and ranked species distributions of biomass and abundance (ABC method).

\section{Materials and methods}

\subsection{Study area}

The "Grande Vasière" study area is located on the continental shelf of the Bay of Biscay around $47^{\circ} \mathrm{N}$ and extends between 3 and $4^{\circ} \mathrm{W}$ off the French Atlantic coast. The "Grande Vasière", muddy sediment, is one of the most important fishing zone in France, where the main commercial species is the Norway lobster Nephrops norvegicus. In the Bay of Biscay, Nephrops is exploited by otter trawl gear, a 1 tonne mobile bottom trawl with a horizontal opening of $10 \mathrm{~m}$, and a $70 \mathrm{~mm}$ mesh. Otter trawls are designed to target efficiently large epibenthic species and penetrate the sediment to a depth of a few centimeters only (Lindeboom and de Groot 1998). The Bay of Biscay is subdivided in ICES-statistical rectangles wherein fishermen have to declare their catches. The Norway lobster fleet fishing effort is concentrated in the north part of the Bay of Biscay. The catches are landed in the French (Brittany) harbours: Saint-Guénolé, Le Guilvinec, Loctudy, Lesconil, Concarneau, Lorient and Quiberon.

\subsection{Sampling strategy}

In May 2001, a bottom sampling survey (INTRIGAS II) was carried out in the study area with RV Côtes de la Manche and replicated in November 2003 by the RV Thalassa (EVHOE 2003 survey) using a $2 \mathrm{~m}$ beam trawl with a $20 \mathrm{~mm}$ codend mesh. The gear was towed for $20 \mathrm{~min}$ at a speed of 2 knots. The prospected areas were measured precisely with the ship's Differential Global Positioning System. Pressure captors were placed on the trawl. This gear is appropriate for sampling large epibenthic invertebrate species, which are typically patchily distributed over a large area, as the beam trawl integrates this small-scale patchiness (Fraueheim 1989; Jennings 1999). The beam trawl sampled macrobenthic 


\section{Undisturbed}

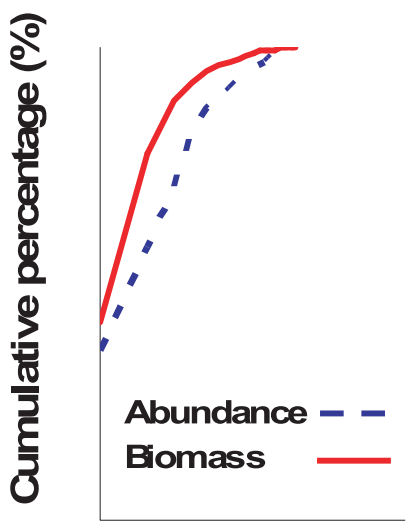

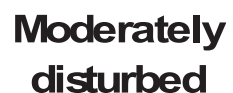

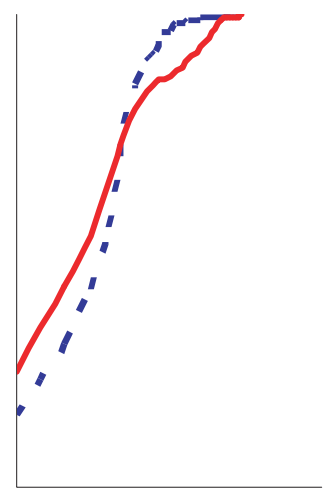

Species rank

\section{Grossly \\ disturbed}

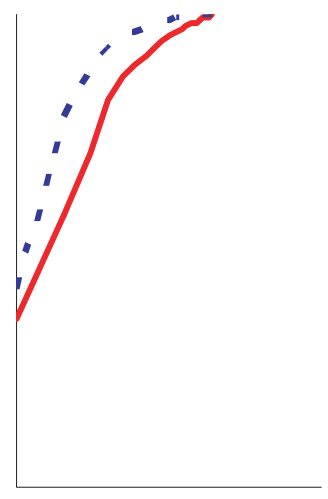

Fig. 1. Theoretical ABC plots for undisturbed, moderately disturbed and grossly disturbed communities. The solid line represents the ranked distribution of biomass in the community and the dashed one represents the ranked distribution of abundance.

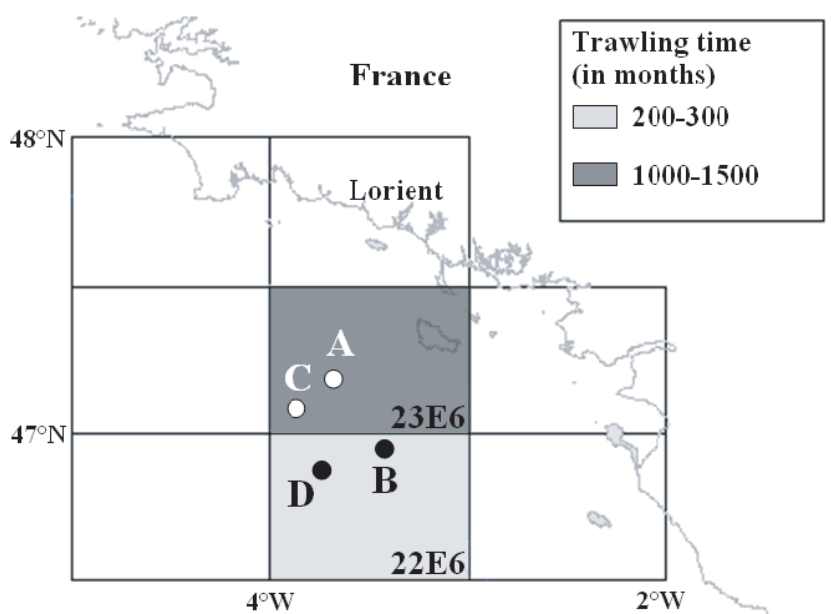

Fig. 2. Locations of the four sampled sites in the Bay of Biscay in 2001 and 2003. Sites A and C are located in a highly fished zone where the time actually spent trawling stands between 1000 and 1500 months per year. B and D are located in a moderately fished zone where the time actually spent trawling stands between 200 and 300 months per year.

invertebrates living on the seabed and to a few centimetres deep in the sediment. Organisms were identified to the specific level. Eight stations were sampled (about $2500 \mathrm{~m}^{2}$ per haul) in 2001 and eleven in 2003. At each station, and for each species, biomass density and numerical density (respectively biomass and abundance hereafter) were measured and expressed for standard $1000 \mathrm{~m}^{2}$ areas. Species richness was also measured.

Stations are distributed near the $100 \mathrm{~m}$ isobath within four different sites called A, B, C and D, two in each of the two areas of differing trawling intensity (Fig. 2). The location of each site was based on the spatial variation in fleet fishing effort in 2001. Fleet fishing effort was not available for the year 2003 but both the exploited areas and the fishing fleets were the same than in 2001 (pers. comm Leloch). Effort data estimated by the Fisheries Monitoring System of IFREMER in each ICES statistical rectangle were first used. Trawling effort expressed as the time actually spent trawling was between 1000-1500 months per year at the two high fishing pressure sites: A and C, in ICES rectangle 23E6. At the moderately trawled sites B and D (ICES 22E6), trawling effort was between 200 and 300 months per year. This large scale measure of effort may not capture the finer-scalepatchiness of trawling activities within a statistical rectangle so we also estimated the local fishing effort. Relative exploitation levels in A-C, and B-D were calculated by assuming that the fishing effort was lower for sites further from a given harbour. Vessels exploiting each sites were identified and numbered and their contributions to the overall effort were estimated by taking into account their technical features (mean ship speed, mean cruise duration, mean number of hauls per cruise, mean fishing season duration) (pers comm. Ollitraut). All the sites were used by the fishery i.e. there was no unfished site. Our results (not shown here) confirmed that $\mathrm{A}-\mathrm{C}$ is actually more frequently trawled than B-D. Besides, the four sites presented similar hydrological and sedimentary features.

\subsection{Analysis of the community structure}

Invertebrate species were sorted a priori in categories considering their potential sensitivity to trawling (Table 1 and Blanchard et al. 2004). These categories were defined taking into account both the direct impact of the gear on the seabed and the subsequent ability of a trawled population to recover (ICES 2003).

- Sensitive species are negatively affected by trawling. They are vulnerable to the direct action of the trawl and their ability to recover is limited.

- Indifferent species are not affected by trawling due to a specific life style or morphology.

- Opportunistic species are sensitive to the physical action of the trawl but they are also mobile scavengers able to profit from the post disturbance conditions, feeding on the organisms returned to the sea or killed by the gear.

For each station, biomass, abundance and number of species were measured in each category. 
Table 1. List of species (codes and taxonomic groups) and their sensitivity to trawling; Indifferent: white; Sensitive: light grey; Opportunistic: dark grey.

\begin{tabular}{|c|c|c|}
\hline Code & Species & Class \\
\hline ACD & Actinauges richardi & Hexocorallia \\
\hline ADP & Adamsia carcinopados & Hexacorallia \\
\hline ALD & Alcyonium digitatum & Octocorallia \\
\hline ALGL & Alpheus glaber & Crustacea \\
\hline ALV & Anapagurus laevis & Crustacea \\
\hline APE & Apporhais pespelicani & Gastropoda \\
\hline ARBA & Arcopagia balaustina & Bivalvia \\
\hline ARLO & Armina loveni & Gastropoda \\
\hline ASL & Astacilla longicornis & Crustacea \\
\hline ASY & Astropecten spp. & Asteroidea \\
\hline ATRO & Atelecyclus rotundatus & Crustacea \\
\hline ATUN & Atelecyclus undecimdentatus & Crustacea \\
\hline $\mathrm{AZCH}$ & Azorinus chamasolen & Bivalvia \\
\hline BRLY & Brissopsis lyrifera & Echinoidea \\
\hline $\mathrm{CAO}$ & Calliostoma granulatum & Gastropoda \\
\hline CHCR & Chlorotocus crassicornis & Crustacea \\
\hline CAPA & Cancer pagurus & Crustacea \\
\hline CRAL & Crangon allmanni & Crustacea \\
\hline CUCU & Cuspidaria cuspidata & Bivalvia \\
\hline CURO & Cuspidaria rostrata & Bivalvia \\
\hline CUP & Phaxas pellucidus & Bivalvia \\
\hline DEEN & Dentalium entalis & Scaphopoda \\
\hline DIBO & Dichelopandalus bonnieri & Crustacea \\
\hline DOLU & Dosinia lupinus & Bivalvia \\
\hline EBCR & Ebalia cranchi & Crustacea \\
\hline GADI & Galathea dispersa & Crustacea \\
\hline GASQ & Galathea squamifera & Crustacea \\
\hline GORH & Goneplax rhomboides & Crustacea \\
\hline HEMA & Heterocrypta maltzani & Crustacea \\
\hline IND & Inachus dorsettensis & Crustacea \\
\hline LECE & Leptometra celtica & Crinoidea \\
\hline LEEL & Leptopentacta elongata & Holothurioidea \\
\hline LID & Liocarcinus depurator & Crustacea \\
\hline LIH & Liocarcinus holsatus & Crustacea \\
\hline MAN & Macropodia tenuirostris & Crustacea \\
\hline MATU & Macropipus tuberculatus & Crustacea \\
\hline MUBA & Munida rugosa & Crustacea \\
\hline NENO & Nephrops norvegicus & Crustacea \\
\hline NUSU & Nucula sulcata & Bivalvia \\
\hline OPOP & Ophiura ophiura & Ophiuroidea \\
\hline PAP & Pagurus pridauxi & Crustacea \\
\hline PEPH & Pennatula phosphorea & Octocorallia \\
\hline PHEC & Philocheras echinulatus & Crustacea \\
\hline PIRU & Pitar rudis & Bivalvia \\
\hline POHE & Polybius henslowi & Crustacea \\
\hline POPU & Porania pulvillus & Asteroidea \\
\hline POSP & Pontophilus spinosus & Crustacea \\
\hline PRNO & Processa nouvelli & Crustacea \\
\hline PTH & Pteria hirundo & Bivalvia \\
\hline SCA & Scalpellum spp. & Crustacea \\
\hline SCAR & Scyllarus arctus & Crustacea \\
\hline SOME & Solenocera membranacea & Crustacea \\
\hline SQDE & Squilla desmaresti & Crustacea \\
\hline THPU & Thracia pubescens & Bivalvia \\
\hline TUC & Turritella communis & Gastropoda \\
\hline VEOV & Timoclea ovata & Bivalvia \\
\hline VIMI & Virgularia mirabilis & Octocorallia \\
\hline UPDE & Upogebia deltaurea & Crustacea \\
\hline
\end{tabular}

For benthic organisms not living too deep in the sediment, direct fishing mortality, i.e. mortality caused by both physical damages and captures, is higher for larger individuals, as smaller ones are pushed aside by the pressure created in front of the moving trawl (Collie et al. 2000). Therefore, one could expect that large organisms may be rarer in highly trawled sites. We used the mean individual weight (the averaged weight of all individuals in a given community) as an additional parameter to analyse the response of communities to bottom trawling. The mean weight of opportunistic organisms was also monitored.

\subsection{ABC method}

The average abundance and biomass were calculated for each species and for each of the four sites in 2001 and 2003. Average ABC plots were then built and differences between biomass and abundance curves were quantified by the measure of $W$ (Warwick and Clarke 1994):

$$
W=\frac{\sum_{j=1}^{S}\left[\left(\sum_{j=1}^{i} b_{j}\right)-\left(\sum_{j=1}^{i} a_{j}\right)\right]}{50(S-1)}
$$

where $W$ is the standardised sum of the differences between each pair of species of cumulative biomass $\left(\sum_{j=1}^{i} b_{j}\right)$ and cumulative abundance $\left(\sum_{j=1}^{i} a_{j}\right)$ values ranked in decreasing order.

$W$ values in highy and moderately exploited sites were statistically compared in 2001 and 2003. The robustness of the ABC method was investigated by comparing sites submitted to similar fishing efforts in 2001 and 2003.

\section{Results}

All the statistical tests performed were realized by comparing stations using one way ANOVAs. Mean sites'results are presented below.

\subsection{Community structure}

\section{Abundance and biomass}

Average values are shown in Table 2. In 2001, total biomass strongly differed among sites (Fig. 4). Fishing effort did not significantly account for those variations $(F=0.212$; $p=0.661$ ). Three opportunistic large species, Munida rugosa, Nephrops norvegicus and Liocarcinus depurator, dominated biomass distibutions in all four sites. The domination of opportunistic species was higher in higly trawled sites while the biomass of sensitive organisms was lower. Consequently, the opportunistic/sensitive biomass ratio was significantly higher in A-C $(F=19.782 ; p=0.004)$.

Variations of total abundance among the different sites were not explained by the fishing effort distribution $(F=$ $0.808 ; p=0.403$ ). Generally, abundance distributions were 
Table 2. Abundance (mean number per $1000 \mathrm{~m}^{2}$ ) and biomass (mean wet weigth in ger $1000 \mathrm{~m}^{2}$ ) of each species collected in 2001 and 2003, in each site (A, B, C and D). Codes and Latin names of species are listed in Table 1. Indifferent species: white, Sensitive: light grey, Opportunistic species: dark grey.

\begin{tabular}{|c|c|c|c|c|c|c|c|c|}
\hline \multicolumn{9}{|c|}{2001} \\
\hline \multirow[b]{3}{*}{ Species } & \multirow{2}{*}{\multicolumn{4}{|c|}{$\begin{array}{c}\text { Abundance } \\
\text { Sites }\end{array}$}} & \multicolumn{4}{|c|}{ Biomass } \\
\hline & & \multicolumn{3}{|c|}{ Sites } & \multicolumn{4}{|c|}{ Sites } \\
\hline & A & B & C & D & A & B & C & D \\
\hline LID & 14.68 & 13.04 & 9.35 & 12.29 & 144.84 & 61.75 & 94.86 & 36.17 \\
\hline NENO & 7.02 & 29.62 & 23.84 & 9.45 & 66.83 & 196.27 & 135.65 & 86.27 \\
\hline CRAL & 5.11 & 6.91 & 5.35 & 1.27 & 5.64 & 6.30 & 5.10 & 0.77 \\
\hline MUBA & 5.11 & 23.01 & 76.44 & 15.18 & 28.11 & 79.21 & 251.37 & 35.74 \\
\hline NUSU & 0.64 & 7.08 & 4.36 & 0 & 0.91 & 5.92 & 3.83 & 0 \\
\hline ALGL & 0 & 8.19 & 3.32 & 4.33 & 0 & 8.19 & 2.28 & 2.75 \\
\hline GORH & 0 & 6.34 & 2.94 & 7.86 & 0 & 38.24 & 15.85 & 26.07 \\
\hline CHCR & 0 & 1.82 & 0.38 & 1.64 & 0 & 3.32 & 0.79 & 1.86 \\
\hline PRNO & 0 & 1.49 & 0 & 0 & 0 & 0.36 & 0.00 & 0 \\
\hline MAN & 0 & 1.28 & 0.38 & 20.24 & 0 & 1.29 & 0.01 & 10.97 \\
\hline ADP & 0 & 1.28 & 0 & 0.25 & 0 & 3.75 & 0.00 & 0.11 \\
\hline VEOV & 0 & 1.00 & 0.71 & 0.00 & 0 & 0.75 & 0.52 & 0.00 \\
\hline SQDE & 0 & 0.66 & 1.47 & 0.51 & 0 & 2.19 & 4.74 & 1.72 \\
\hline PAP & 0 & 0.58 & 0 & 0.00 & 0 & 8.66 & 0.00 & 0 \\
\hline VIMI & 0 & 0.50 & 0 & 5.46 & 0 & 0.96 & 0.00 & 4.56 \\
\hline BRLY & 0 & 0.41 & 0 & 0.55 & 0 & 5.27 & 0.00 & 1.38 \\
\hline POHE & 0 & 0.41 & 0 & 0 & 0 & 4.31 & 0.00 & 0 \\
\hline CUCU & 0 & 0.25 & 0 & 0 & 0 & 0.22 & 0.00 & 0 \\
\hline APE & 0 & 0.25 & 0 & 0 & 0 & 0.51 & 0.00 & 0 \\
\hline PEPH & 0 & 0.25 & 0 & 0.55 & 0 & 0.13 & 0.00 & 1.21 \\
\hline ALD & 0 & 0.12 & 0 & 1.78 & 0 & 0.48 & 0.00 & 0.49 \\
\hline TUC & 0 & 0 & 0.38 & 6.21 & 0 & 0 & 0.42 & 2.96 \\
\hline DIBO & 0 & 0 & 0.38 & 0.00 & 0 & 0 & 0.47 & 0 \\
\hline ASY & 0 & 0 & 0 & 29.53 & 0 & 0 & 0 & 71.58 \\
\hline SCA & 0 & 0 & 0 & 28.48 & 0 & 0 & 0 & 1.70 \\
\hline ASL & 0 & 0 & 0 & 7.73 & 0 & 0 & 0 & 0.56 \\
\hline ALV & 0 & 0 & 0 & 4.31 & 0 & 0 & 0 & 0.91 \\
\hline IND & 0 & 0 & 0 & 2.40 & 0 & 0 & 0 & 0.67 \\
\hline PTH & 0 & 0 & 0 & 2.28 & 0 & 0 & 0 & 0.56 \\
\hline $\mathrm{CAO}$ & 0 & 0 & 0 & 1.85 & 0 & 0 & 0 & 7.60 \\
\hline MATU & 0 & 0 & 0 & 1.31 & 0 & 0 & 0 & 5.03 \\
\hline GADI & 0 & 0 & 0 & 1.02 & 0 & 0 & 0 & 0.01 \\
\hline HEMA & 0 & 0 & 0 & 0.55 & 0 & 0 & 0 & 0.22 \\
\hline SOME & 0 & 0 & 0 & 0.55 & 0 & 0 & 0 & 1.58 \\
\hline POSP & 0 & 0 & 0 & 0.55 & 0 & 0 & 0 & 0.30 \\
\hline POPU & 0 & 0 & 0 & 0.55 & 0 & 0 & 0 & 3.62 \\
\hline ACD & 0 & 0 & 0 & 0.55 & 0 & 0 & 0 & 12.47 \\
\hline LECE & 0 & 0 & 0 & 0.51 & 0 & 0 & 0 & 0.61 \\
\hline CUP & 0 & 0 & 0 & 0.25 & 0 & 0 & 0 & 0.03 \\
\hline HIA & 0 & 0 & 0 & 0.25 & 0 & 0 & 0 & 0 \\
\hline HEN & 0 & 0 & 0 & 0.25 & 0 & 0 & 0 & 1.20 \\
\hline \multicolumn{9}{|c|}{2003} \\
\hline LID & 10.08 & 11.56 & 22.45 & 4.53 & 59.89 & 66.07 & 117.17 & 24.86 \\
\hline MUBA & 6.16 & 16.03 & 50.72 & 2.52 & 69.30 & 64.14 & 193.13 & 10.07 \\
\hline CRAL & 3.80 & 1.30 & 28.41 & 0 & 1.53 & 0.48 & 12.62 & 0 \\
\hline NENO & 3.08 & 3.39 & 5.83 & 2.18 & 18.39 & 35.05 & 26.75 & 11.75 \\
\hline ALGL & 1.54 & 15.22 & 13.42 & 2.49 & 1.09 & 13.10 & 10.17 & 1.09 \\
\hline SOME & 0.59 & 2.31 & 2.53 & 4.03 & 0.71 & 4.03 & 2.81 & 5.88 \\
\hline GORH & 0.59 & 25.15 & 3.64 & 11.18 & 3.76 & 146.61 & 16.58 & 50.29 \\
\hline POSP & 0.47 & 2.94 & 4.44 & 3.34 & 0.17 & 2.44 & 2.57 & 1.77 \\
\hline MAN & 0.47 & 0.66 & 0 & 2.83 & 0.15 & 0.49 & 0 & 1.21 \\
\hline SQDE & 0.24 & 1.93 & 0.22 & 2.00 & 0.59 & 3.63 & 0.41 & 3.65 \\
\hline BRLY & 0.24 & 3.77 & 2.99 & 2.85 & 6.51 & 61.91 & 69.78 & 37.77 \\
\hline LIH & 0.24 & 0 & 0 & 0.00 & 2.37 & 0 & 0 & 0 \\
\hline OPOP & 0.12 & 0 & 0 & 2.97 & 0.84 & 0 & 0 & 21.37 \\
\hline
\end{tabular}


Table 2. continued.

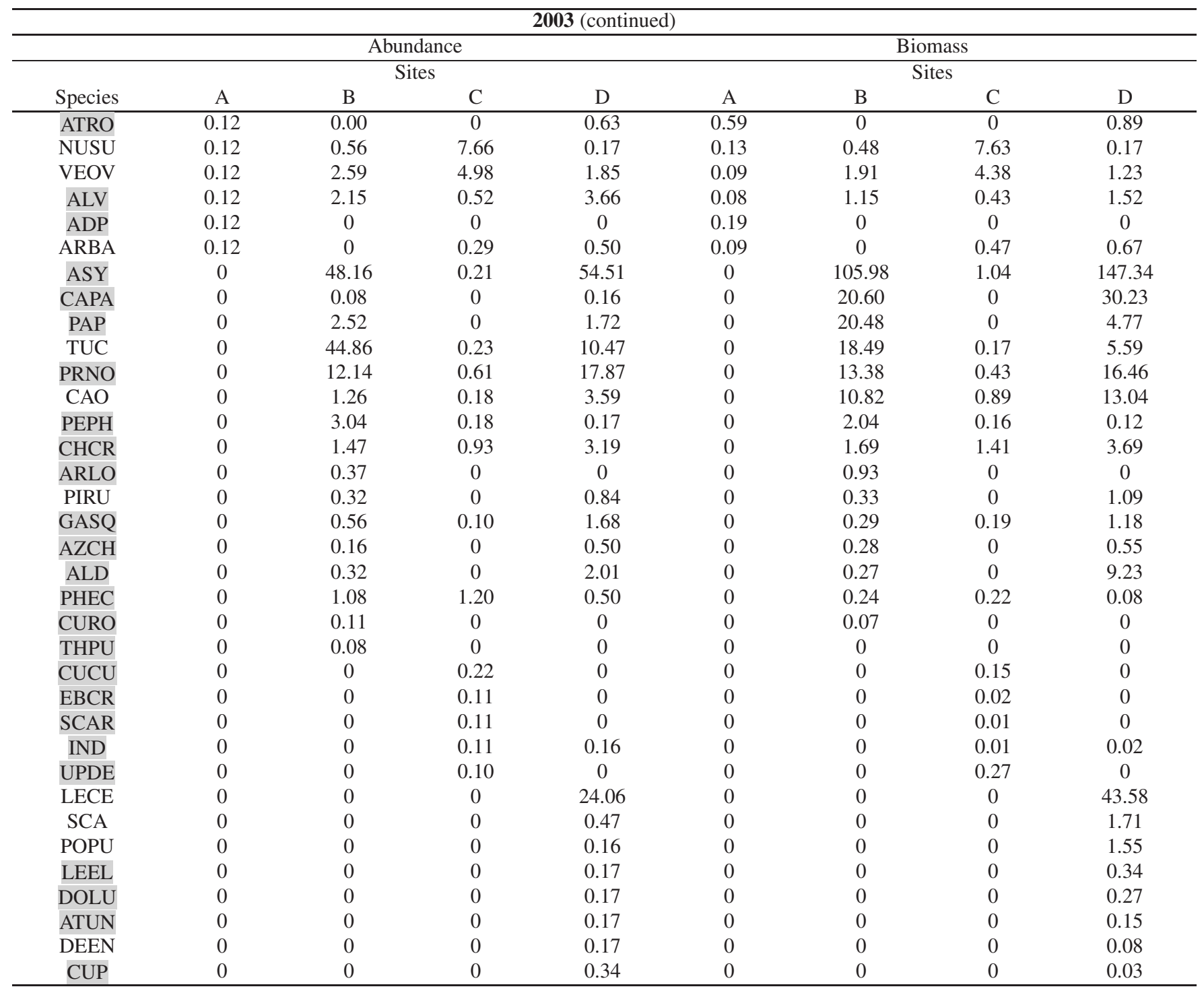

more homogeneous than biomass distributions. Munida rugosa, Nephrops norvegicus and Liocarcinus depurator were the dominant species in sites A, B and C. In D, a sensitive starfish, Astropecten irregularis, and an indifferent cirriped Scalpellum scalpellum dominated the distribution of abundance. The opportunistic/sensitive abundance ratio was significantly higher in $\mathrm{AC}(F=14.273 ; p=0.009)$.

In 2003, the total biomass and the total abundance appeared not to be linked to fishing effort $(F=2.336 ; p=0.161$; $F=2.832 ; p=0.127)$. Opportunistic/sensitive biomass ratios were significantly higher in $\mathrm{A}-\mathrm{C}(F=8.586 ; p=$ 0.017). Opportunistic/sensitive abundance ratios were also higher in A-C but the trend was not significant $(F=4.501$; $p=0.063$ ). In A-C, Munida rugosa, $N$. norvegicus and $L$. depurator dominated biomass distributions. In moderately exploited sites, dominant species were sensitive organisms. Thus, in B, Astropecten irregularis and decapod crustacean Goneplax rhomboides were the major species, and in site $\mathrm{D}, A$. irregularis, G. rhomboides and crinoïde Leptometra celtica dominated. In site $\mathrm{B}$, the sensitive species A. irregularis, and the indifferent gastropoda Turittela communis represented $42 \%$ of the total abundance. In site D, A. irregularis and $L$. celtica strongly dominated the abundance distribution.

In all prospected sites in 2001 and 2003, relative biomass and abundance of indifferent species did not differ significantly between moderately and highly exploited sites (in 2001, $F=$ 5.871; $p=0.052 ; F=2.682 ; p=0.153$. In 2003, $F=2.180$; $p=0.174 ; F=1.788 ; p=0.214)$.

\section{Species richness}

For the two sampling years, the number of opportunistic and indifferent species (in 2001, $F=1.670, p=0.244$ and $F=1.260, p=0.305 ;$ in $2003, F=1.990, p=0.193$ and $F=3.710, p=0.086)$ did not differ in a significant way between A-C and B-D (Fig. 3). However, the number of sensitive species (in 2001, $F=11.49, p=0.015$; in 2003, $F=10.25$, 

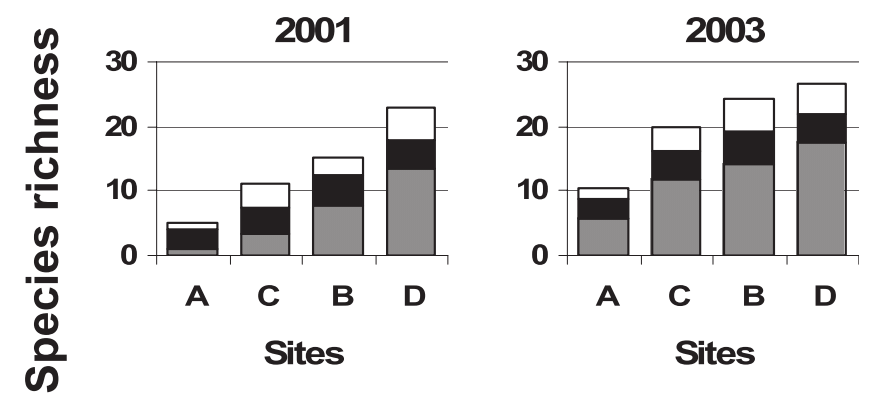

Fig. 3. Species richness of sensitive (圆 Sen), opportunistic ( $\square$ Opp) and indifferent ( $\square$ Ind) organisms in highly (A-C) and moderately (B-D) exploited sites in 2001 and 2003.
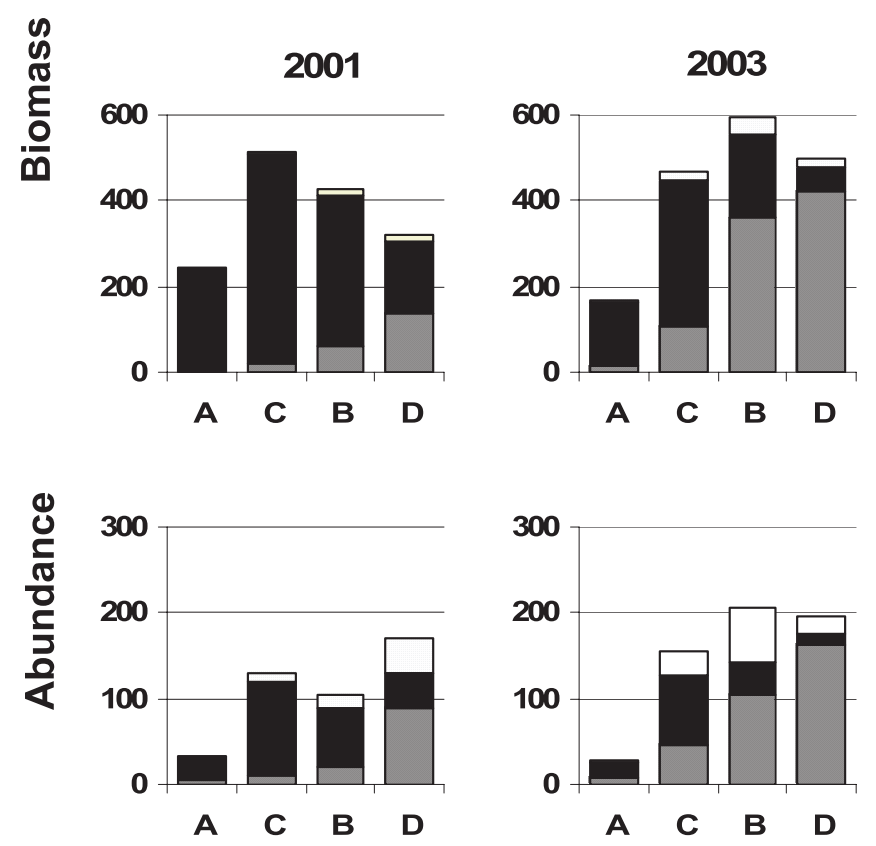

Fig. 4. Biomass (wet weight in g per $1000 \mathrm{~m}^{2}$ ) and abundance (number of individuals per $1000 \mathrm{~m}^{2}$ ) of sensitive Sen), opportunistic ( $\square$ Opp) and indifferent ( $\square$ Ind) organisms in highly (A-C) and moderately (B-D) exploited sites in 2001 and 2003.

$p=0.011$ ) and the total species richness (in 2001, $F=9.452$, $p=0.022$; in 2003, $F=10.115, p=0.011$ ) was significantly lower in highly trawled stations. The total number of species sampled in sites A-C and B-D showed a non significative increasing trend $(F=2.220, p=0.155)$ between 2001 and 2003.

\section{Size structure}

Mean individual weights (Table 3) were not significantly different between moderately and higly exploited sites (in $2001, F=0.064, p=0.132$; in 2003, $F=0.820, p=0.391$ ), suggesting that higher fishing efforts did not imply the disappearance of large organisms. Regarding the opportunistic species, the mean weigth was higher than the mean individual weight in both moderately and highly exploited sites.
Table 3. Biomass (wet weight in $\mathrm{g}$ per $1000 \mathrm{~m}^{2}$, mean \pm SD) of individual and opportunistic species in moderately and highly trawled sites in 2001 and 2003.

\begin{tabular}{ccccc}
\hline & \multicolumn{4}{c}{ Sampling years } \\
\cline { 2 - 5 } & \multicolumn{4}{c}{2001} \\
Benthic Trawling Intensity \\
\hline & Moderate & High & Moderate & High \\
\hline Individual weight & $3.3 \pm 1.3$ & $5.3 \pm 2.0$ & $3.1 \pm 1.0$ & $4.3 \pm 3.0$ \\
Opportunist weight & $6.1 \pm 1.8$ & $7.0 \pm 1.8$ & $5.4 \pm 1.0$ & $5.3 \pm 2.6$ \\
\hline
\end{tabular}

Table 4. Values of $W$-statistics, ranked in decreasing order, in 2001 and 2003.

\begin{tabular}{cc}
\hline Stations & $W$-statistics \\
\hline \multicolumn{2}{c}{2001} \\
\hline AA1 & 0.248 \\
BB1 & 0.110 \\
B2 & 0.099 \\
B3 & 0.127 \\
CC1 & 0.024 \\
C3 & 0.024 \\
D1 & 0.129 \\
DD1 & 0.119 \\
\hline \multicolumn{2}{c}{2003} \\
\hline AA1 & 0.122 \\
AA2 & 0.155 \\
AA3 & 0.404 \\
BB1 & 0.089 \\
B2 & 0.101 \\
B3 & 0.024 \\
C1 & 0.121 \\
C2 & 0.007 \\
C3 & 0.226 \\
DD1 & 0.064 \\
D1 & 0.033 \\
\hline
\end{tabular}

\subsection{Abundance-biomass comparison}

In 2001, A, B and D sites showed undisturbed patterns with the biomass curve above the abundance curve (Fig. 5). C appeared as a moderatly disturbed community with biomass and abundance curves crossing each other. Values of $W$-statistics (Table 4) for A-C and B-D were not significantly different $(F=0.112, p=0.750)$. In 2003, A and C showed undisturbed patterns, whereas $\mathrm{B}$ and $\mathrm{D}$ appeared as moderatly disturbed. The differences between A-C and B-D were not significantly different $(F=3.188, p=0.108)$. The highly exploited sites A and $\mathrm{C}$ showed similar patterns between the two sampling years $(F=0.621, p=0.457)$. On the contrary, B and D patterns differed significantly between 2001 and 2003 ( $F=11.644$, $p=0.009)$.

\section{Discussion}

In 2001 and 2003, opportunistic species strongly dominated distributions of biomass and abundance at highly trawled sites. Furthermore, total species richness and sensitive species richness were higher at moderately trawled sites. These results support the hypothesis that benthic trawling is a major source 


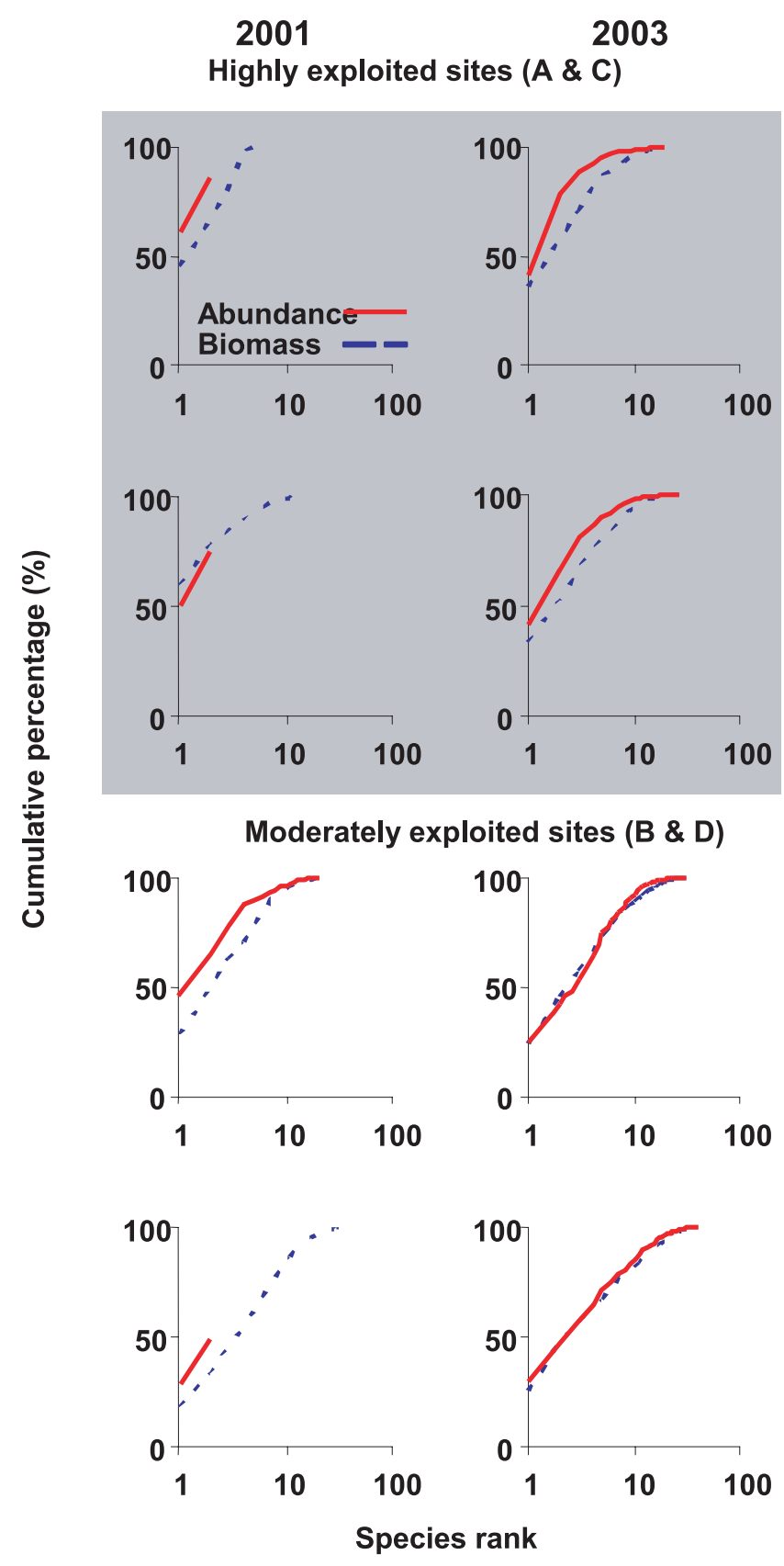

Fig. 5. ABC plots in highly (A-C) and moderately (B-D) exploited sites in 2001 and 2003. The solid line represents the ranked distribution of biomass in the community and the dashed one represents the ranked distribution of abundance.

of disturbance for soft-bottom communities. The mean opportunist weight was also shown to be higher than the mean individual weight at all sites, which is not consistent with the theory underlying the $\mathrm{ABC}$ method.

\section{Inter-annual variability}

Sampling with benthic trawls usually implies high variability among replicates (Blanchard et al. 2004) and it is then necessary to discuss the reliability of our data set before analysing any result. In particular, the temporal variability in biomass dominance observed at the two moderately trawled sites (a domination of opportunistic species in 2001 followed by a domination of sensitive species in 2003) should be reexamined. The sampling effort developed for this study may have been inappropriate to draw an acurrate picture of benthic macrofaunal communities. Such an assumption finds support in the higher species richness observed in 2003 at all sites. At least two hypothesis related to sampling could be proposed to explain this high inter-annual variability. First, the sampling effort may have failed to integrate the scattered spatial distribution of large epibenthic organisms. As an extreme example, one of the dominant species collected at moderately trawled sites, Astropecten irregularis, has a very patchy spatial distribution due to its tendency to aggregate (Leloch 2004). Limited sampling may underestimate the abundance of such patchily distributed species. Indeed, the probability to "miss" partially such populations aggregated on restricted areas is not negligible. Secondly, the trawling effort actually experienced by benthic organisms in sites A, B, C or D might differ from our expectations. In addition with sampling considerations, a natural seasonal variation of the species composition between May 2001 and November 2003 appears as an obvious potential reason of the variability between the two surveys. Yet most large macrofaunal species live several years so that adult benthic stages are present over the whole year within communities. Some of the collected species may undertake seasonal migrations, leading to high temporal variability in biomass and abundance. Astropecten irregularis has been reported to migrate seasonally in coastal zones (Freeman 2001). However, the seasonal environmental variability which triggers these migrations is strongly dampened at $100 \mathrm{~m}$ deep and is therefore unlikely to affect population dynamics in the study area. Other stimuli could be considered for deep populations, for instance an increase of the organic matter flow towards the benthic system following spring phytoplanktonic blooms.

\section{Benthic trawling impact}

The IFREMER Fisheries Monitoring System provides estimates of trawling effort at the scale of ICES statistical rectangles, assuming that it is uniformly distributed over these large areas. Such an assumption is clearly a simplification. The calculation of more local trawling efforts was our answer to overcome this major difficulty. This second approach yielded results consistent with the IFREMER estimates, suggesting that the sites $\mathrm{A}$ and $\mathrm{C}$ were effectively more frequently trawled than sites $\mathrm{B}$ and $\mathrm{D}$. Such a conclusion is also underpinned by previous studies of fishing impact in the Grande Vasière (Blanchard et al. 2004; Leloch 2004) which show more disturbed communities in the A-C area.

Despite evidence of inter-annual variability due to sampling, non ambiguous structural differences between sites B$\mathrm{D}$ and $\mathrm{A}-\mathrm{C}$ are visible. The two strongly trawled sites $\mathrm{A}$ and $\mathrm{C}$ exhibit lower sensitive biomass and abundance and a lower diversity of sensitive species. The removal of sensitive species at highly exploited sites has been widely reported by authors and is interpreted as an alteration of the structure of communities (Dayton et al. 1995). One may object that the domination 
of a few opportunistic species at the two moderately trawled sites in 2001 also supports evidence of disturbance. However, these dominant opportunistic species, namely the squat lobster Munida rugosa, the Norway lobster Nephrops norvegicus and the swimming crab Liocarcinus depurator, are not exclusive scavengers. They are also competitive predators that fully belong to typical undisturbed communities (Groenewold 2000). What their presence means then depends on the species composition of the communities they are embedded in. B-D communities are species rich and include organisms typically found in undisturbed environments such as Leptometra celtica, a fragile epibenthic sessil species.

It is worth to notice that communities do not experience any reduction of their total biomass or abundance in highly exploited sites. This result differs from what was observed at ecologically similar sites in the North Sea, where the trawling effort is considerably higher than in the Bay of Biscay (Jennings 2001). This suggests that the threshold beyond which exploitation would cause the general collapse of benthic communities has not been reached yet in the Grande Vasière.

\section{Large species at highly trawled sites}

We have shown that dominant species in disturbed conditions were large-bodied organisms. This result is surprising regarding as small-bodied species with high population growth rates should be more adapted to settle in frequently disturbed systems (MacArthur 1962).

The domination of large opportunists such as Munida rugosa, Nephrops norvegicus and Liocarcinus depurator at highly trawled sites could result from their higher ability to escape fishing gears. However, these three species are often caught by benthic trawlers in the North Sea (Bergmann 2001a,b; Bergmann 2002a). Lindeboom and de Groot (1998) estimate that no macrofaunal epibenthic invertebrate is mobile enough to avoid modern bottom trawls.

Another hypothesis which could explain the domination of large-bodied organisms at frequently trawled sites is linked to the production of discards by fisheries. By definition, opportunistic species are able to feed on discards and organisms killed or injured by benthic fishing gears. How such additional trophic resources influence the dynamics of opportunistic populations is not well understood (Lindeboom and de Groot 1998). However, it has been suggested that they may locally support populations of scavengers within frequently trawled communities, where the competition with sensitive species is low (Groenewold 2000; Bergmann 2002b). At frequently trawled sites, the trophic resources provided by discards could counter-balance the negative effect of trawling on large-bodied opportunistic organisms. The patchy distribution of trawling disturbance (Rijnsdorp 1998; Ragnarsson 2003) may allow large opportunists to survive in small intouched areas from which they could move into trawl tracks and feed on dead and injured individuals. This hypothesis admits a limit beyond which trawling effort is too high to allow the persistence of opportunistic populations.

\section{Interpretation of $\mathrm{ABC}$ plots}

In contrast with the theory that underlies the ABC method, higher trawl efforts in our study zone do not shift benthic macrofaunal communities toward increasing domination by small-bodied opportunistic species.

Within a community, the size of dominant species determines the relative position of biomass and abundance curves. Therefore, the unusual domination of large-bodied opportunistic species at highly trawled sites is likely to bias the results of the ABC method. This is confirmed by the analysis of $\mathrm{ABC}$ plots which yield inconsistent disturbance diagnosis. Large crustaceans Munida rugosa, Nephrops norvegicus and Liocarcinus depurator dominated at highly trawled sites A 2001, A 2003 and C 2003 and at moderatly trawled sites B and D 2001. Consequently, ABC plots were similar for all of these sites, with the biomass curve lying above the abundance curve. In that case, the ABC method contradictly concludes that two very different groups of communities experienced the same level of disturbance. In B and D 2003, communities were dominated by Astropecten irregularis and Leptometra celtica, two sessile epibenthic species typically found in undisturbed environments. Because A. irregularis and L. celtica are smallbodied organisms, the $\mathrm{ABC}$ method diagnosted a very unlikely high level of disturbance.

One may question the importance of such a result as the range of sizes (i.e. organisms captured by the $20 \mathrm{~mm}$ mesh sampling trawl) we considered could exclude from the study the small opportunists that are predicted to dominate in disturbed communities. The study of a wider (microfauna + macrofauna) size range of organisms could be suggested. However, the persistence of large-bodied macrobenthic organisms at high trawling effort would have altered the reliability of the $\mathrm{ABC}$ method in any case. On the Grande Vasière, the main commercial species belong to benthic macrofauna. It was therefore highly desirable to identify the specific pitfalls linked to the monitoring of these large organisms. The ABC method had proved to be a powerful indicator of impact of diverse kinds of disturbance on benthic communities and was then a promising tool that needed to be tested in the context of the ecosystem approach of fisheries. Our study highlights and important caveat of the method and will be useful for managers and policy makers who will have to select properly a panel of indicators to implement the sustainable exploitation of the stocks.

\section{Conclusion}

The ABC method is based on a general ecological theory which correctly describes the structural succession experienced by most communities submitted to increasing disturbance. This theory admits exceptions. Several studies actually emphasize particular situations in which the ABC method is not appropriate (Beukema 1988; Dauer 1993). The present work confirms that fishing negatively affects the state of health of benthic communities. However, the use of the ABC method is not always relevant to quantify these impacts. Above all, our study shows that synthetic tools as such indicators are "black boxes". It underlines the need for comprehensive ecological 
analysis of communities before using any type of ecosystem indicators.

Acknowledgements. We are grateful to François Leloc'h (IRD, avenue Jean Monnet, BP 171, 34203 Sète Cedex, France) and Christian Hily (LEMAR, IUEM, place Copernic, 29280 Plouzané, France) who provided many useful ecological and biological data on the ecosystem of the Grande Vasière. IFREMER DRV-RH made this research possible. We thank Anthony Ollitraut (Ifremer, 8 rue François Toullec, 56100 Lorient, France) for his help in estimating local fishing efforts.

\section{References}

Bergmann M., Wieczorek S.K., Moore P.G., Atkinson R.J.A., 2002a, Utilisation of invertebrates discarded from the Nephrops fishery by variously selective benthic scavengers in the west of Scotland. Mar. Ecol. Prog. Ser. 233, 185-198.

Bergmann M., Wieczorek S.K., Moore P.G., Atkinson R.J.A., 2002b, Discard composition of the Nephrops fishery in the Clyde Sea area, Scotland. Fish. Res. 57, 169-183.

Bergmann M., Beare D.J., Moore P.G., 2001a, Damage sustained by epibenthic invertebrates discarded in the Nephrops fishery of the Clyde Sea area, Scotland. J. Sea Res. 45, 105-118.

Bergmann M., Moore P.G., 2001b, Survival of the decapod crustaceans discarded in the Nephrops fishery of the Clyde Sea area, Scotland. ICES J. Mar. Sci. 58, 163-171.

Beukema J.J., 1988, An evaluation of the ABC method (abundance/biomass comparison) as applied to macrozoobenthic communities living on tidal flats in the Dutch Wadden Sea. Mar. Biol. 99, 425-433.

Blanchard F., Leloch F., Hily C., Boucher J., 2004, Fishing effects on diversity, size and community structure of the benthic invertebrate and fish megafauna on the Bay of Biscay of France. Mar. Ecol. Prog. Ser. 280, 249-260.

Collie J.S., Hall S.J., Kaiser M.J., Poiners I.R, 2000, A quantitative analysis of fishing impacts on shelf-sea benthos. J. Anim. Ecol. 69, 785-798.

Connel J.H., 1978, Diversity in tropical rain forests and coral reefs. Science 199, 1302-1310.

Cury P., Christensen V., 2005, Quantitative ecosystem indicators for fisheries management. ICES J. Mar. Sci. 62, 307-310.

Dauer D.M., Luckenbach M.W., Rodi A.J Jr., 1993, Abundance biomass comparison ( $\mathrm{ABC}$ method): effects of an estuarine gradient, anoxic/hypoxic events and contaminated sediments. Mar. Biol. 116, 507-518.

Dayton P.K., Thrussh S.F., Agardy M.T., Hofman R.J., 1995, Environmental effects of marine fishing. Aquat. Conserv. 5, 205-232.

Duplisea D.E., Jennings S., Warr K.J., Dinmore T.A., 2002, A sizebased model of the impacts of bottom trawling on benthic community structure. Can. J. Aquat. Sci. 59, 1785-1795.
Frauenheim K., Neumann V., Theil H., Turkay M., 1989, The distribution of the larger epifauna during summer and winter in the North Sea and its suitability for environmental monitoring. Senckenb. Marit. 20, 101-118.

Freeman S.M., Richardson C.A., Seed R., 2001, Seasonal Abundance, Spatial Distribution, Spawning and Growth of Astropecten irregularis (Echinodermata: Asteroidea). Estuar. Coast. Shelf Sci. 53, 39-49.

Groenewold S., Fonds M., 2000, Effects on benthic scavengers of discards and damaged benthos produced by the beam-trawl fishery in the southern North Sea. ICES J. Mar. Sci. 57, 1395-1406.

Hall S.J., 1999, The effects of fishing on marine ecosystems and communities. Blackwell Science, Oxford.

ICES, 2003, Report of the ICES Advisory Committee on fishery managment. on ecosystems. ICES CM 2003/ACE: 05.

Jennings S., Lancaster J., Woolmer A., Cotter J., 1999, Distribution, diversity and abundance of epibenthic fauna in the North Sea. J. Mar. Biol. Assoc. UK 79, 385-399.

Jennings S., Pinnegar J.K., Polunin N.V.C., Warr K.J., 2001, Impacts of trawling disturbance on the trophic structure of benthic invertebrate communities. Mar. Ecol. Prog. Ser. 213, 127-142.

Kaiser M.J., Edwards D.B., Armstrong P.J., Radford K., Lough N.E.L., Flatt R.P., Jones H.D., 1998, Changes in megafaunal benthic communities in different habitats after trawling disturbance. ICES J. Mar. Sci. 55, 353-361.

Kaiser M.J., Ransay K., Richardson C.A., Spence F.E., Brand A.R., 2000, Chronic fishing disturbance has changed shelf sea benthic community structure. Ecology 69, 494-503.

Leloch F., 2004, Structure, fonctionnement, évolution des communautés benthiques des fonds meubles exploités du plateau continental Nord Gascogne. Thèse de doctorat de l'Université de Bretagne Occidentale, Brest.

Lindeboom H.J., de Groot S.J. (Eds.) 1998, The effects of different types of fisheries on the North Sea and Irish Sea benthic ecosystems. Netherlands Institute of Sea Research, Texel.

MacArthur R.H., 1962, Some generalized theorems of natural selection. Proc.Nat. Acad. Sci. USA, 48, 1893-1897.

Ragnarsson S.A., Steingrmsson S.A., 2003, Spatial distribution of otter trawl effort in Icelandic waters: comparison of measures of effort and implications for benthic community effects of trawling activities. ICES J. Mar. Sci. 60, 1200-1215.

Rijnsdorp A.D., Buys A.M., Storbeck F., Visser E.G., 1998, Microscale distribution of beam trawl effort in the southern North Sea between 1993 and 1996 in relation to the trawling frequency of the sea bed and the impact on benthic organisms. ICES J. Mar. Sci. 55, 403-419.

Warwick R.M., 1986, A new method for detecting pollution effects on marine macrobenthic communities. Mar. Biol. 92, 557-562.

Warwick R.M., Clarke K.R., 1994, Relearning the ABC: Taxonomic changes and abundance/biomass relationships in disturbed benthic communities. Mar. Biol. 118, 739-744.

Warwick R.M., Pearson R., Ruswahyuni T.H., 1987, Detection of pollution effects on marine macrobenthos: further evaluation of the species abundance/biomass method. Mar. Biol. 5, 193-200. 